\title{
INTERACTIVE TEACHING METHODS AS MEANS OF FOREIGN LANGUAGE COMMUNICATIVE COMPETENCE FORMATION OF UNIVERSITY STUDENTS
}

\section{MÉTODOS DE ENSINO INTERATIVO COMO MEIO DE FORMAÇÃO DE COMPETÊNCIA DE COMUNICAÇÃO DE LÍNGUA ESTRANGEIRA DE ESTUDANTES UNIVERSITÁRIOS}

\author{
MÉTODOS DE ENSEÑANZA INTERACTIVOS COMO MEDIO DE LAFORMACIÓN DE \\ COMPETENCIAS COMUNICATIVAS EN LENGUA EXTRANJERA DE ESTUDIANTES \\ UNIVERSITARIOS
}

\author{
Ramilya F. MUSTAFINA ${ }^{1}$ \\ Irina A. SHCHERBAKOVA ${ }^{2}$ \\ Marina S. ILINA ${ }^{3}$
}

\begin{abstract}
The article depicts highlights in creating unknown dialect open ability by utilizing the intuitive instructing strategies. The bearings of building up the understudies' unknown dialect informative skill are resolved. Experimentation on abilities in the improvement of this fitness was done based on association between members. A similar examination of the outcomes in test and control bunches is proposed. The logical oddity of the article is that it portrays the adequacy of the experience of utilizing participation innovation and the online stage Technology Entertainment Design in the creating of unknown dialect informative fitness of understudies.
\end{abstract}

KEYWORDS: Communicative ability. Interactive technology. Online platforms. Teaching techniques. Educational means. Educational process. Teamwork.

RESUMO: $O$ artigo descreve os destaques na criação da habilidade aberta de dialeto desconhecido, utilizando as estratégias de instrução intuitivas. As dificuldades de construir a habilidade informativa de dialeto desconhecido são resolvidas. A experimentação de habilidades na melhoria dessa aptidão foi feita com base na associação entre os membros. Um exame semelhante dos resultados em grupos de teste e controle é proposto. A estranheza lógica do artigo é que ele retrata a adequação da experiência de utilização da inovação de participação e do palco online Technology Entertainment Design na criação de dialeto desconhecido para adequação informativa de understudies.

PALAVRAS-CHAVE: Lingua estrangeira. Competência comunicativa. Tecnologias interativas. Plataforma online. Métodos de ensino. Processo educacional. Trabalho em equipe.

\footnotetext{
${ }^{1}$ Kazan Federal University (KPFU), Kazan - Russia. Assistant of the Department of English Philology and Intercultural Communication. ORCID: https://orcid.org/0000-0002-0376-3412. Email: rfmustafina@kpfu.ru

${ }^{2}$ Kazan Federal University (KPFU), Kazan - Russia. Senior Lecturer of the Department of English Philology and Intercultural Communication. ORCID: https://orcid.org/0000-0002-1017-6515. E-mail: shereri@mail.ru

3 Kazan Federal University (KPFU), Kazan - Russia. Department of English Philology and Intercultural Communication. ORCID: https://orcid.org/0000-0002-7310-1254. E-mail: steelmar@yandex.ru
}

Rev. EntreLínguas, Araraquara, v. 7, n. esp. 1, p. 76-85, fev. 2021 e-ISSN: 2447-3529 
RESUMEN: El artículo describe los aspectos más destacados en la creación de la capacidad de apertura de dialectos desconocidos mediante la utilización de estrategias de instrucción intuitiva. Se resuelven los rumores de desarrollar la habilidad informativa dialectal desconocida de los alumnos. La experimentación sobre las habilidades en la mejora de esta aptitud se realizó en base a la asociación entre miembros. Se propone un examen similar de los resultados en racimos de prueba y control. La rareza lógica del artículo es que retrata la idoneidad de la experiencia de utilizar la innovación participativa y el diseño de entretenimiento tecnológico en el escenario en línea en la creación de un dialecto desconocido para la aptitud informativa de los estudiantes suplentes.

PALABRAS CLAVE: Lengua extranjera. Competencia comunicativa. Tecnologias interactivas. Plataforma online. Métodos de enseñanza. Proceso educativo. Trabajo en equipo.

\section{Introduction}

The principal objective of professional instruction is to prepare a certified pro to a fitting level and profile, serious in the work market, familiar with his/her calling and arranged in related fields of action, prepared for consistent expert development, social and expert portability.

It is hard to overestimate the significance of information on an unknown dialect in the advanced universe of Internet innovations. It is practically difficult to envision the life of an individual today who doesn't have a clue about an unknown dialect, on the grounds that most of the current methods for correspondence are centered on individuals who communicate in an unknown dialect. Subsequently, L. Bulanova expects that development of the learning cycle with regards to multifaceted exchanges alongside shaping the informative ability of things to come expert is at the center of present-day educational practice (TUGUSHEVA et al., 2018).

The presentation of a capability-based way to deal with higher expert instruction arrangement is pointed toward improving connection with the work market, improving specialists' competitiveness, content updating, and proper learning conditions (BARTH et al., 2007).

The foundation for forming the foreign communicative competence of learners is utilizing the interactive methods as well as dialogic models of interaction on the basis of the extension and designing of several positions of free communication; mastering the cultural and linguistic-cultural awareness; the talent to operate with diverse data sources; and holding the motive to acquire a foreign tongue (LESTER, 2014; BARAHOVICH, 2000). 
Following the modern specialist's requirements, skilled experimentation on forming the foreign language communicative competence of learners of non-linguistic departments of the University investigating English has been suggested.

\section{Methods}

The main methods of investigation are as follows:

- Hypothetical - methodological investigation of logical, rational, psycho - instructive, instructive writing on research point; examination, correlation and speculation of instructors' involvement with schools, professional schools, colleges;

- Investigation and results from systematization of understudies' exercises (imaginative work), instructive analysis, perception, discussion, review, displaying, strategy for master assessments, the technique for numerical insights.

Dependability and legitimacy of exploration results are guaranteed by reference to key work on the issue by the solidarity of exact and hypothetical techniques relating to its topic, points, and goals. It is additionally guaranteed by the complex character of instructive test utilizing numerical techniques to get information tentatively and by adequate agent selections with the creators' cooperation in test work.

\section{Results and discussion}

Given the survey, roughly $63 \%$ of pupils think that a modern specialist's communicative competence is vital in the professional field. A foreign language Knowledge permits them to cooperate in personal communication as well as professional one with indigenous speakers.

Based on the results, nearly $67 \%$ of understudies highlighted a fairly low degree of advancement of their aptitudes in unknown dialect open capability, clarifying this through the poor quality of the methodological association of the instructive cycle.

Approximately $44 \%$ of the pupils were totally content since they deliver the following solutions "concentrate over reading and interpreting information, not over communication in an educational manner, " and "linguistics and emotional obstacle.

Approximately one-quarter of the students (24\%) remarked that the present practice is insufficient to promote communicative competence in an alien tongue. In contrast, the causes were: "inadequate understanding of a foreign language in the grammar area, vocabulary" (32\%), 
"inadequate linguistic and cultural understanding" (36\%), "shortage of communication abilities" (49\%).

Solely $33 \%$ were content with the educational means to promote communicative competence.

The significant incentives for communicative activities were adopted by nearly $65 \%$ of learners ("work overseas", "career", "freelancing", and "communication in social networks", "future opportunities "). The reasons for collaboration were taken by roughly $35 \%$ of them ("learning the conventions and culture of native speakers", "the capacity to know a wide variety of information in a foreign tongue", "grasping the attitude of local speakers") (PODESTA et al., 2014).

The relative outcomes are exhibited in Table 1.

Table 1 - The outcomes of the investigation of the degree of improvement of unknown dialect open ability in the exploratory and control bunches toward the start and toward the finish of the term

\begin{tabular}{|c|c|c|c|c|c|}
\hline \multirow{2}{*}{$\begin{array}{c}\text { Level of } \\
\text { development }\end{array}$} & \multicolumn{2}{|c|}{ At the start of the term } & \multicolumn{2}{|c|}{ At the end of the } & \multirow{2}{*}{$\begin{array}{c}\text { The total dynamics } \\
\text { EG / CG, } \%\end{array}$} \\
\hline & $\mathrm{EG}, \%$ & $\mathrm{CG}, \%$ & $\mathrm{EG}, \%$ & $\mathrm{CG}, \%$ & \\
\hline \multicolumn{6}{|c|}{ Testing } \\
\hline High-level & 16 & 12 & 32 & 15 & $+16 /+3$ \\
\hline Medium-level & 36 & 37 & 48 & 45 & $+12 /+8$ \\
\hline Low-level & 48 & 51 & 20 & 40 & $-28 /-10$ \\
\hline \multicolumn{6}{|c|}{ Case tasks } \\
\hline High-level & 14 & 15 & 26 & 18 & $+12 /+3$ \\
\hline Medium-level & 29 & 31 & 43 & 35 & $+14 /+4$ \\
\hline Low-level & 57 & 54 & 31 & 47 & $-26 /-7$ \\
\hline
\end{tabular}

Source: Developed by the authors

The actual dynamics of the growth of strange language communicative competence of learners in the experimental collection implies that its expansion enables not solely to promote foreign language communicative skills but also to recognize the origin of learning individualization, to produce a healthy psychological environment that offers the efficient utilization of multiple activities, and the construction of productive thinking. It is qualified to take note of that training dependent on intelligent techniques in general is of fundamental significance during the time spent limiting the language hindrance and strengthening intragroup discourse movement (TUGUSHEVA et al., 2018).

The practical parts of the methodological association of the instructive cycle in the system of the arrangement and advancement of unknown dialect open ability featured: 
- Analytical: Pursuit of the likely original communicative conditions for professional and private communication, prospects of enhancing the condition and examination of the results achieved;

- Design: communicative situations modeling, complexity consideration, and so forth;

- Communicative: Handling the communicative procedure and efficient cooperation among its members, giving learners effective feedback, increasing the strength to ask questions, debate their situation, trade knowledge, and build and sustain productive connections with the partakers of the communicative procedure.

Considering the study outcomes, it can be concluded that the obstacle of adopting one or another interactive technology concentrated on alien language communicative cooperation is that the learning procedure presents functional skills improvement. Furthermore, a mentor ought to pay particular attention to the minimal lexis for the preferred subject and phraseological parts that include the national character and carry it way more clearly than usual vocabulary (KAJUMOV et al., 2017).

The study's sample was made up of virtually 200 learners of non-linguistic University departments investigating English. Both groups contained 100 members.

The study was carried out to recognize the foreign language communicative competence significance in their adopted profession. The questionnaire was made up of 2 open question blocks.

The initial block was directed at the self-assessment of the students in communicative competence level and its importance for professional action and individual growth.

The next block is pointed toward distinguishing the degree of hierarchical and methodological preparation in the improvement of informative ability in an unknown dialect by understudies.

Evaluating the organizational level and methodological practice in developing this competence by pupils exhibited disappointment with creating interaction among learners, the design, and their being useless in real-life situations

In order to evaluate the improvement of communicative competence level, examination and resolution of samples were performed. The examination involved a set of assignments for each of the communicative competence elements. Pupils launched around 40 test assignments in speaking, listening, reading, and writing in order to evaluate language information and 
abilities and five case assignments to evaluate socio-cultural and socio-linguistic competence in native tongue positions. The accurate accomplishment of each task was measured in five cases.

The following criteria assessed the decision of the case: analysis of the information obtained in these cases:

- The capacity to identify significant information;

- Capacity to switch viewpoints and set up a work plan on an obstacle;

- The capacity to discover answers to obstacles and address them all;

- The capacity to negotiate, solve questions;

- The capacity to provide rational answers.

As per this dissemination, the degree of development of unknown dialect informative fitness of understudies of the control and trial bunches didn't vary the results of testing fundamentally.

The developmental step remained for one term. Over the course of one-semester, traditional educational techniques were employed in the group of control. The pilot group did a deliberate job of forming and developing foreign language communicative communication on the basis of collaboration technology. It was arranged teamwork where the learner has to discuss multiple communication circumstances and events as well as the online platform of Technology Entertainment Design (TED-ed).

Analyzing the mentioned technology has been performed in the subsequent course topics: "Generation Z: Something which is Unique regarding the Young Generation?", "How can the youth state Their Identity?" (SALEH, 2013), "Why do the youth prefer a subculture?"(MACSUGA GAGE et al., 2012)

\section{Summary}

Therefore, given the interpretation of the outcomes acquired over the course of the test, we can remark the principal suggestions to model the educational method of additional learning a foreign tongueat the University:

- The textbooks overall compliance, contributions, and their flexibility to educational organizations following the individual and professional demands of learners, universal criteria, and the labor market's demands; 
- $\quad$ structure and content Compliance of the element with the purposes and intentions of the communicative activations of the pupils;

- Concentrate on enhancing the communicative competence, acquiring information and experiences guaranteed by interactive assignments in order to organize and review the information obtained.

\section{Conclusion}

Active-teaching techniques employed throughout the term enables students to be subject to the communicative procedure: to establish a purpose, to design its success, to separately gain experience, to assess the outcomes of their activities. Arranging the development of dialect informing fitness of understudies settled at the University using intellectual improvements, particularly collaboration technology and the TED-ed platform, empowers learners to remain engaged in dynamic communication projects.

Additionally, the technology provides learners with movement under the circumstances of continuous variability of the social conditions through increasing their knowledge; produces important foreign language information, frequent renewal of the material under survey, informing one another in dialogue, enabling each other to promote their personal abilities.

A vast diversity of collaboration forms permits learners to receive new tasks: a member over the communicative procedure, a counselor, and an opponent. Concerning the collaboration technology to develop foreign tongue communicative competence, the student's personal business is involved in the cooperation.

The cooperation technology outcomes have a significant effect on the outcome of the whole team's personal and group work, which permits them to utilize information and experiences and develop them in the discussion, making decisions, and calculation of answers to it. The likelihood of utilizing interactive means lets us produce 2 sorts of motive: selfmotivation, which promotes understanding and enables you to place it into effect; motive is developed and improved by individual and collective work and confirms that a learner is able to apply a foreign tongue for communication goals.

Hence, advanced foreign language education with the advantage of learning technology is setting up the policy of education individualization; it occurs in a healthy psychological environment, it involves the efficient application of multiple actions and providing for developing productive thought, and so forth. 
ACKNOWLEDGEMENT: This study has been carried out via the Russian Government Program of Competitive Growth of Kazan Federal University.

\section{REFERENCES}

BALL, D. L.; THAMES, M. H.; PHELPS, G. Content knowledge for teaching what makes it special? Journal of teacher education, v. 59, n. 5, p. 389-407, 2008.

BARAHOVICH, I. I. Формирование коммуникативной компетентности студентов педагогического колледжа [The formation of communicative competence of students at pedagogical College]. PhD Candidate Thesis. Krasnojarsk, 2000.

BARTH, M. et al. Developing key competencies for higher education. International Journal of Sustainability in Higher Education, v. 8, n. 4, p. 416-430, 2007. DOI:

https://doi.org/10.1108/14676370710823582

BLACK, P.; WILIAM, D. Assessment and classroom learning. Assessment in Education, v. 5, n. 1, p. 1-74, 1998. DOI: https://doi.org/10.1080/0969595980050102

BROADFOOT, P. Empowerment or performativity? English assessment policy in the late twentieth century. In: British Educational Research Association Conference University of Sussex at Brighton. Brighton: University of Sussex, 1999.

DOLZHIKOVA, A.; KURILENKO, V.; BIRYUKOVA, Y.; GLAZOVA, O.; ARZUMANOVA R. Translation-oriented reading of scientific-technical texts vs ordinary reading: psychological and psycholinguistic aspects. XLinguae, v. 11, n. 2, p. 24-33, 2018. DOI: https://doi.org/10.18355/xl.2018.11.02.03

GUZHELYA, D.; BIRYUKOVA, Y.; SHCHERBAKOVA, O; AKHNINA, K.; MASLOVA, I. Linguodidactic modelling in teaching foreign languages to bilingual children. Revista Espacios, v. 40, n. 8, p. 1-17. 2018.

HALL, K.; HARDING, A. Level descriptions and teacher assessment in England: towards a community of assessment practice. Educational research, v. 44, n. 1, p. 1-16. 2002. DOI: https://doi.org/10.1080/00131880110081071

JOHNSON, D. H.; JOHNSON, F. P. Joining together: Group theory and group skills. 12. ed. New Jersey: Prentice-Hall, 2017.

KAJUMOV, D. F. et al. The imagery of spiritual concepts in teaching process expressed by Phraseological units of the English, Tatar and Turkish languages. Man In India, v. 97, n. 3, p. 597-609, 2017.

KHAYRUTDINOV, R. R.; NIKOLAEVA, O. A.; KOZLOVA, J. A.; SOKOLOVA, I. I. Bilingual modality translation of American literature. European Research Studies Journal, v. 20 (Special Issue), p. 458-468, 2017.

LEE, S. J.; LIU, Y. E.; POPOVIC, Z. Learning individual behavior in an educational game: A data-driven approach. In: INTERNATIONAL CONFERENCE ON EDUCATIONAL DATA 
MINING, 7., 2014, Indianapolis. Proceedings [...]. Indianapolis, Indiana: EDM, 2014. p. 114-121.

LESTER, S. Professional standards, competence and capability. Higher Education, Skills and Work-based Learning, v. 27, n. 7, p. 31-43, 2014. DOI:10.1108/HESWBL0420130005

MACSUGA GAGE, A. S. et al. Effective teaching practices for a positive classroom environment. Beyond Behavior, v. 22, n. 1, p. 14-22, 2012. DOI:

https://doi.org/10.1177/107429561202200104

NARAG, R. M. Sojourning of foreign students at cagayan state university: a case of intercultural communicative competence 2016. (Unpublished Dissertation) - Cagayan State University, Tuguegarao City, 2016.

PODESTA, J.; PRITZKER, P.; MONIZ, E.; HOLDER, J.; ZENTS, J. Big data: seizing opportunities, preserving values. Washington, DC: Executive Office of the President, 2014. Available in: https://obamawhitehouse.archives.gov/sites/default/files/docs/20150204_Big_Data_Seizing_ Opportunities_Preserving_Values_Memo.pdf. Access: 11 sep. 2019.

SALEH, S. E. Understanding Communicative Competence. University Bulletin, v. 3, n. 5, p. 101-110, 2013.

SPENCER-OATEY, H.; FRANKLIN, P. Intercultural interaction: A multidisciplinary approach to intercultural communication (research and practice in applied linguistics). Basingstoke: Palgrave Macmillan, 2009. DOI: https://doi.org/10.1057/9780230244511

TELEZHKO, I.; BIRYUKOVA, Y.; KURILENKO, V. A model for forming tolerance in profession-oriented text translators as part of the process of developing their socio-cultural competence. XLinguae, v. 12, n. 1, p. 116-124. 2019. DOI:

https://doi.org/10.18355/XL.2019.12.01.09

TUGUSHEVA, E. Z. et al. Forming Anticorruption Competence Through Teaching a Professionally-oriented Language Course. Modern Journal of Language Teaching Methods, v. 8, n. 11, p. 429-436, 2018.

UKEssays. Communicative competence in language teaching. 2018. Available in: https://www.ukessays.com/essays/englishlanguage/communicativecompetenceinthelanguagec lassroomenglishlanguageessay.php?vref=1. Access: 11 sep. 2019.

WINTHER, E.; KLOTZ, V. K. Spezifika der beruflichen Kompetenzdiagnostik — Inhalte und Methodologie. Zeitschrift für Erziehungswissenschaft, v. 7, n. 1, p. 9-32, 2014. DOI: $10.1007 / \mathrm{s} 1161801304554$

ZEER, E. F.; SYMANYUK, E. Е. Реализация компетентностного подхода в системе инновационного образования [Realization of the competencebased approach in the system of innovative education]. Innovacionnye proekty i programmy v obrazovanii, v. 4, p. 15 $20,2014$. 


\section{How to reference this article}

MUSTAFINA, R. F.; SHCHERBAKOVA, I. A.; ILINA, M. S. Interactive teaching methods as means of foreign language communicative competence formation of university students. Rev. EntreLínguas, Araraquara, v. 7, n. esp. 1, p. 76-85, fev. 2021. e-ISSN: 2447-3529. DOI: https://doi.org/10.29051/el.v7iEsp1.14874

Submitted: $28 / 10 / 2020$

Required revisions: $19 / 12 / 2020$

Approved: 13/01/2021

Published: $28 / 02 / 2021$ 